\title{
ARBUSCULAR MYCORRHIZAE IN AGRICULTURAL AND FOREST ECOSYSTEMS IN CHILE
}

\author{
Fernando Borie, Rosa Rubio, Alfredo Morales, Gustavo Curaqueo and \\ Pablo Cornejo* \\ Center of Amelioration and Sustainability of Volcanic Soils, Scientific and Technological \\ Bioresource Nucleus (BIOREN), Universidad de La Frontera, P.O. Box 54-D, Temuco, Chile. \\ *Corresponding author: pcornejo@ufro.cl
}

\begin{abstract}
Arbuscular mycorrhizal (AM) association plays a key role in the sustainability of terrestrial plant ecosystems, in particular those presenting limitations for the establishment and subsequent growth of plants. In Chile, more than $50 \%$ of arable soils are originated from volcanic ashes, showing in general several constraints to crop production, such as low $\mathrm{pH}$, high exchangeable aluminum content and low levels of available P. Under these conditions, the management of AM fungal propagules using adequate cultural management practices emerges as a successful alternative in order to maximize the positive effects of AM symbiosis on plant growth in these types of soil. This review presents the results of several years of research about the effect of different agronomic and forest management practices on the density and functionality of the native fungal populations in volcanic soils from Southern Chile, and their subsequent effect on the improvement of soil characteristics. These investigations have contributed to a better understanding of the role played by AM symbiosis in such soils and provide guidance on the most appropriate alternatives to increase its presence and functionality.
\end{abstract}

Keywords: Andisol, management practices, mycorrhizal propagules, N sources, P fractions, Ultisol.

\section{INTRODUCCION}

Volcanic ash-derived soils have a great significance in the economies of many countries especially in Asia, Africa and America. In Chile, volcanic soils support the bulk of agricultural and forestry production, covering more than $5.3 \times 10^{6}$ hectares, which represent about 50-60\% of the country's arable land (Besoaín, 1985). Andisols and Ultisols are the two main orders found in Southern Chile. In spite of many advantageous edaphic and climatic characteristics, these soils have other properties which can constraint plant growth. They include high Padsorption capacity with a concomitant low $\mathrm{P}$ availability, high soil organic matter (SOM) content with a variable humification degree and, sometimes, high acidity levels which originate a concomitant $\mathrm{Al}, \mathrm{Mn}$ and $\mathrm{H}^{+}$ phytotoxicities (Borie and Rubio, 1999).

Clay fraction of volcanic soils contains large amounts of allophane, an amorphous aluminum silicate, together with allophane-like secondary minerals as well as $\mathrm{Fe}$ and $\mathrm{Al}$ oxides. The dominance of fungal (free or symbiotic) biomass related to total microbial $\mathrm{C}$ in the microbial communities of volcanic soils tends to make them highly reactive (Zunino et al., 
1982a). These characteristics and interactions create a highly reactive soil environment, especially in relation to $\mathrm{P}$ adsorption. This is reflected in the following biological properties of these soils which can help to understand the complexity of overall biogeochemical cycles in such habitats, such as: (i) strong stabilization of indigenous organic matter and organic compounds when they are added to the soils (Zunino et al., 1982b); (ii) high rates of microbial synthesis of humic-type macromolecules (Zunino et al., 1982c) and (iii) high enzymatic activities, including urease (Borie and Fuentealba, 1982), phenoloxidase (Peirano et al., 1992), and acid phosphatase (Borie et al., 1993; Alvear et al., 2006; 2007).

The objective of this review is to report some of the researches related to interactions between arbuscular mycorrhizal (AM) fungi and agricultural or forestry plants growing in volcanic soils from Southern Chile, especially focused on the main management practices used by local farmers in crop production. The use of fertilizers, lime, crop rotation, tillage systems and its effect on mycorrhizal activity will be here highlighted.

\section{Phosphorus and mycorrhizae in volcanic soils}

Soil management practices play a crucial role in $\mathrm{P}$ cycling in volcanic soils. In this context, tillage and crop rotation effect on $\mathrm{P}$ shifting from fractions with different lability has been studied by our group in an Andisol (Vilcún soil). Thus, it has been reported that the addition of the equivalent of 3 ton $\mathrm{ha}^{-1}$ fresh vegetal residues to Vilcún soil, with $4 \mathrm{mg} \mathrm{kg}^{-1}$ of available-P produced a major increase of labile-P fraction, suggesting an increased organic $\mathrm{P}\left(\mathrm{P}_{\mathrm{o}}\right)$ mineralization rate (Borie et al., 2002).
The effect of tillage systems and crop rotation on $\mathrm{P}$ fractions lability has been studied earlier in the same Vilcún soil suggesting that, in general, no-tillage (NT) increases the levels of labile-Pi (inorganic P) extracted with $\mathrm{NaHCO}_{3}$ in comparison with conventional tillage (CT). In addition, $\mathrm{P}$-fractions $\left(\mathrm{P}_{\mathrm{i}}\right.$ and $\left.\mathrm{P}_{\mathrm{o}}\right)$ extracted with $\mathrm{NaOH}$, also considered to be potentially labile, have been found at higher levels in NT than CT treatments suggesting a shifting from more recalcitrant $\mathrm{P}$ forms towards $\mathrm{P}$ forms with higher lability (Redel et al., 2007). In this context, the volcanic-ash derived soils in Chile show a particular behaviour and properties as soil system due to their unusual composition characterized by high allophane and stabilized humus content. These soils constitute excellent models for studying both natural and man-induced AM effect on plant nutrition and soil ecology sustainability. Therefore, the effect of native AM fungus Glomus etunicatum inoculation on wheat growth was studied in a natural volcanic soil fertilized with soluble $\mathrm{P}$ or with partially acidulated rock-phosphate (pa-RP) at two rates (17 and $\left.86 \mathrm{~kg} \mathrm{P} \mathrm{ha}{ }^{-1}\right)$. In addition, yield, plant $\mathrm{P}$ acquisition, and $\mathrm{AM}$ colonized root length were measured. The influence of these treatments on AM mycelium and spore production, as well as on soil phosphatase (P-ase) activity was determined. Mycorrhizal inoculation increased significantly the extent of $\mathrm{P}$ plant acquisition, spore number, length of extraradical mycelium, and P-ase activity when compared with indigenous AM fungi fertilized with pa-RP, at the level of $86 \mathrm{~kg} \mathrm{P} \mathrm{ha}{ }^{-1}$ (Rubio et al., 2003). In concordance with these results, the remaining available $\mathrm{P}$ was depressed in the experimental soil without inoculation.

A negative impact of soluble $P$ application in inoculated soil was noted in the P-ase activity, and also in the effectiveness of the inoculum in relation 
to $\mathrm{P}$ plant acquisition. In the inoculated soil and fertilized with pa-RP (86 kg P ha $\left.{ }^{1}\right)$, the enhancement of P-ase activity was related to high mycelium development and spore formation. Phosphorus plant acquisition in inoculated plants ranged from 4.96 to $11.57 \mathrm{mg} \mathrm{pot}^{-1}$ when $86 \mathrm{~kg} \mathrm{P}$ $\mathrm{ha}^{-1}$ of pa-RP is applied compared with the same amount of soluble P (Figure 1). Such results highlight the higher benefits obtained with partially soluble phosphate
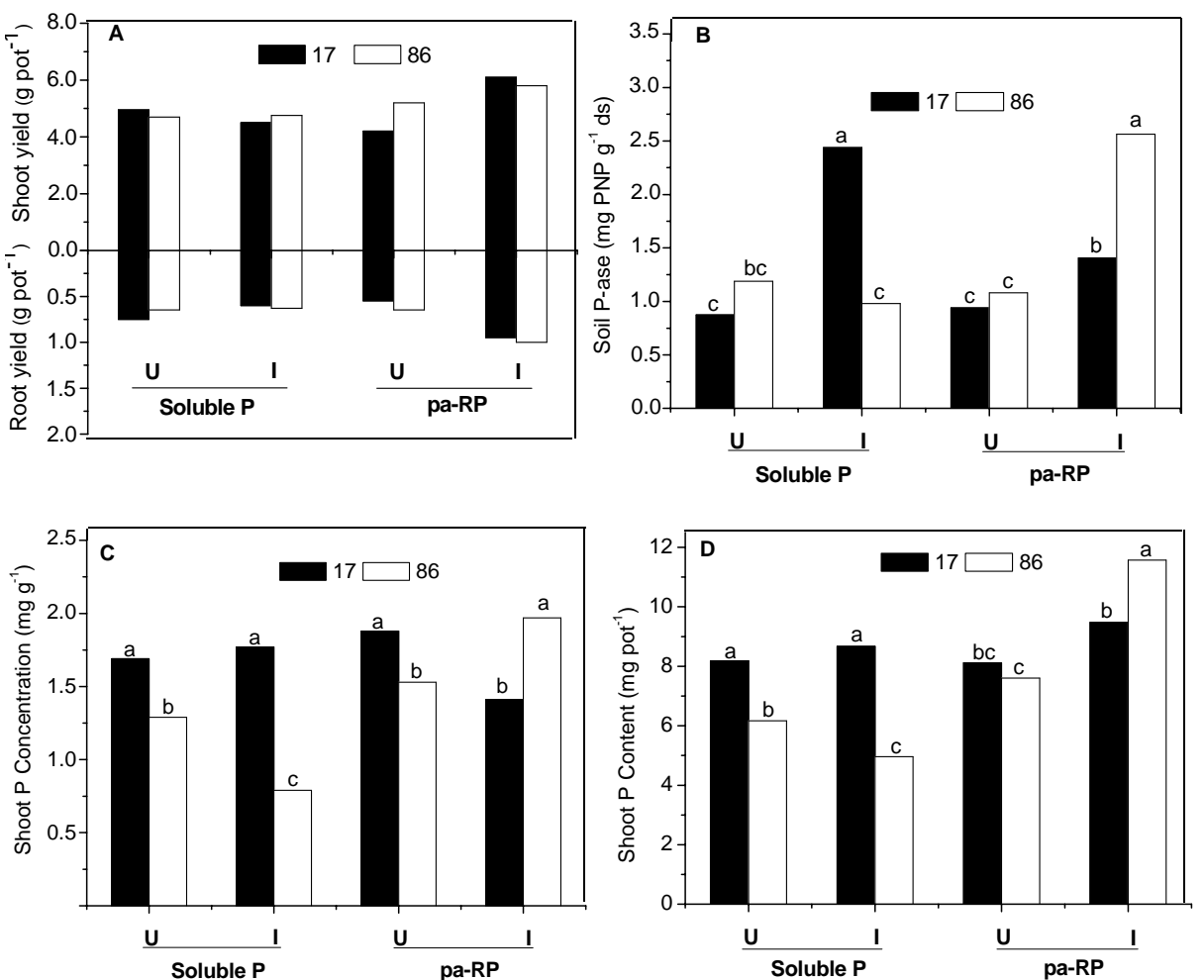

Figure 1. Mycorrhizal inoculation effect on shoot and root biomass (A), soil P-ase activity (B), $\mathrm{P}$ concentration (C) and shoot $\mathrm{P}$ content (D) of wheat growing in a Vilcún soil fertilized with soluble P or pa-RP at two levels (17 and $\left.86 \mathrm{~kg} \mathrm{P} \mathrm{ha}^{-1}\right)$ and inoculated (I) or not (U) with a native strain of Glomus etunicatum. Values with different letters for each P source indicate significantly different means ( $\mathrm{p} \leq 0.05)$ by means of Duncan's test (adapted from Rubio et al., 2003).

More studies are needed to fully biological and chemical mechanism understand the unusual and unique operating in Chilean volcanic soils related 
to the application of P-fertilizers. Undoubtedly, the allophane physicochemical activity should be incorporated as a condition that is permanently cooperating to keep equilibrated phosphate plant nutrition processes in these soils in an ecological manner. As far as we are able to perform this, we will develop the best agronomic management to attain the full yield capacity by volcanic soil systems.

\section{Nitrogen and mycorrhizal propagules in volcanic soils}

Nitrogen fertilization is a habitual practice used by farmers in intensive agriculture systems mainly in cereal-legume rotation. Thus, the application of different $\mathrm{N}$ sources (in particular $\mathrm{NO}_{3}^{-}$and $\mathrm{NH}_{4}^{+}$) is of special relevance, since they represent an important fraction of cations or anions absorbed and/or accumulated by plants, affecting directly soil $\mathrm{pH}$, due to the physiological extrusion of $\mathrm{H}^{+}$or $\mathrm{OH}^{-}$ions by the roots (Stange et al., 1995; Gerendás et al., 1997). Particularly, $\mathrm{NH}_{4}{ }^{+}$ also strongly influences the reduction of soil $\mathrm{pH}$ through $\mathrm{H}^{+}$generation produced by the nitrification process (Martens, 2001). These rhizospheric changes will directly affect the solubility and mobility of several nutrients (Siqueira and Moreira, 1997) and the activity of various groups of microorganisms, including both symbiotic and free-living species (Jeffries and Barea, 2001). Arbuscular mycorrhizal fungal activity in acidic soils is of particular relevance, since it favors root absorption of typically limited elements in this type of soil, especially $\mathrm{P}$ (as previously mentioned), $\mathrm{N}$ and some microelements (Clark et al., 1999; Clark and Zeto, 2000; Borie et al., 2002). Several studies showed that different agronomic practices can affect AM functionality as well as spore density, mycelia and colonized roots present in the soil. Among others, crop system, rotation design and amount and type of the used fertilizer are of particular relevance (Mendoza and Borie, 1998; Borie and Rubio, 1999; Jeffries and Barea, 2001).

On the other hand, it has been demonstrated that extraradical AM fungal hyphae can uptake $\mathrm{NH}_{4}{ }^{+}$as $\mathrm{NO}_{3}{ }^{-}$from the soil (Johansen, 1999; Bago et al., 2001; Hawkins and George, 2001), in addition to significant amounts of N-organic and amino acids (Hawkins et al., 2000). However, only a high-affinity $\mathrm{NH}_{4}^{+}$ transporter expressed in extraradical mycorrhizal hyphae has been characterized up to now (López-Pedrosa et al., 2006). Additionally, functional AM can generate important $\mathrm{pH}$ changes in the mycorrhizosphere, as it has been detected in various assays using in vitro culture systems (Bago et al., 1996; Bago and Azcón-Aguilar, 1997). It has been observed that the development of mycelium in the presence of $\mathrm{NO}_{3}^{-}$is associated with a $\mathrm{pH}$ increase, and, the opposite occurs in $\mathrm{NH}_{4}^{+}$presence. Despite this, there is no concordance in respect to the effect of fertilization with different $\mathrm{N}$ sources on mycorrhizal plants. Some studies suggest the preference for $\mathrm{NO}_{3}{ }^{-}$ (Azcón et al., 1992), while others recommend the preference for $\mathrm{NH}_{4}^{+}$ (Cuenca and Azcón, 1994), with genotypical variations within the same plant species, mainly in limited $\mathrm{N}$ environments (Nakamura et al., 2002).

In our case, some studies about the effect of contrasting $\mathrm{N}$ sources $\left(\mathrm{NO}_{3}{ }^{-}\right.$and $\mathrm{NH}_{4}^{+}$) on the development of AM symbiosis have been carried out in an Andisol from Southern Chile (Vilcún series soil). Among other reports Cornejo et al. (2007) found that fertilization with $\mathrm{N}-\mathrm{NO}_{3}{ }^{-}$promoted an earlier development of the different symbiosis components. Thus, in early stages of a wheat crop, mycorrhizal root colonization was significantly higher, compared with urea 
application as $\mathrm{N}$ source using an ecotype of the native fungus $G$. etunicatum, as above (Table 1). Then, in advanced wheat growth stages (grain maturity), the plants fertilized with $\mathrm{N}_{-} \mathrm{NO}_{3}{ }^{-}$had a higher proportion of active mycelium. Finally, at postharvest, the density of the remaining spores was also favored when $\mathrm{N}_{-} \mathrm{NO}_{3}{ }^{-}$ was used, considering both soils to being inoculated with $G$. etunicatum as soils with native populations of AM fungi (Figure 2; Cornejo et al., 2007; Cornejo et al., 2008b). The aspect mentioned above would also be dependent on the used plant genotype, since studies with two wheat cultivars usually cropped in Southern Chile (Otto and Metrenco) showed great differences in the density of the nspores remaining in soil (at postharvest stage). Thus, in Metrenco cultivar fertilized with $\mathrm{N}^{-\mathrm{NO}_{3}}{ }^{-}$more than 4000 AM fungal spores per $100 \mathrm{~g}$ of soil were observed, which represent four-fold higher than those observed in Otto cultivar fertilized with urea (Cornejo et al., 2008b). The latter aspect is particularly important, because one of the main agricultural activities developed in volcanic soils from Southern Chile are annual crops, and the choice of cultivars and $\mathrm{N}$ sources, as in the previous case, may lead to the presence of more effective AM fungi propagules for the next crop in the succession. In this sense, Cornejo et al. (2009), simulating a wheatoat succession, found that the continuous application of N-nitrate sources contributed not only to increase mycorrhizal colonization in the second crop in the succession, but also a significant increase in soil $\mathrm{pH}$ was observed (Figure 3). However, those beneficial effects were further enhanced when fertilization with nitric $\mathrm{N}$-sources were applied together with a tillage system without producing soil disturbation. This is probably due to the fungal network remaining intact and functional for the second crop, thus increasing infective AM fungi inoculum potential in the soil (see Kabir, 2005, for references). Finally, in terms of nutrition it has been observed that $\mathrm{N}-\mathrm{NO}_{3}{ }^{-}$ application compared with fertilization using $\mathrm{N}-\mathrm{NH}_{4}{ }^{+}$contributes to improve the absorption of essential nutrients, such as $\mathrm{K}, \mathrm{Zn}$ and $\mathrm{Cu}$ in wheat plant (Table 2), while decreasing the contents of usually phytotoxic elements, such as $\mathrm{Mn}$ and $\mathrm{Al}$, which are often found in high amounts in Andisols (Cornejo et al., 2008c). Therefore, the choice of one or another Nsource is particularly important for farmers in Southern Chile, because the use of ammoniacal fertilizers, in spite of producing higher acidity and collateral phytotoxicities is more convenient as their prices are lower compared with $\mathrm{N}$-nitrate ones.

\section{Tillage systems and mycorrhizae in volcanic soils}

Tillage modifies physical and chemical soil environment in which soil microorganisms live, thereby affecting their number, diversity and activity. However, soil disturbance generally has the greatest impact on biological properties, including both free and symbiotic fungal populations like AM fungi. Interest in more ecologically sustainable agricultural systems is rising with increasing recognition of agricultural intensification that can adversely affect environmental quality. In this sense, Borie et al., (2006) have recently reported the effect of tillage system on some soil characteristics such as $\mathrm{pH}, \mathrm{C}, \mathrm{N}$ and $\mathrm{S}$ levels, total and available $\mathrm{P}$ contents, levels of some $\mathrm{P}$ forms associated with organic matter, and its relationship with AM propagules, such as root colonization, spore number and total and active hyphal length in an Ultisol. Measurements were carried out at the sixth year of an on- 
Table 1. Development of the arbuscular mycorrhizal symbiosis of Glomus etunicatum in wheat (Triticum aestivum L., cv. "Otto") as influenced by the $\mathrm{N}$ source $\left(\mathrm{NH}_{4}^{+}\right.$or $\mathrm{NO}_{3}^{-}$) at 120, 150 and 240 days after sowing (DAS) (adapted from Cornejo et al., 2007).

\begin{tabular}{|c|c|c|c|c|c|c|c|c|}
\hline \multirow{2}{*}{$\begin{array}{l}\text { Crop } \\
\text { stage }\end{array}$} & \multirow{2}{*}{$\begin{array}{c}\mathrm{N} \\
\text { source }\end{array}$} & $\begin{array}{c}\text { Total root } \\
\text { length }\end{array}$ & $\begin{array}{l}\text { Colonized } \\
\text { root length }\end{array}$ & Colonization & $\begin{array}{c}\text { Total } \\
\text { hyphae }\end{array}$ & $\begin{array}{l}\text { Active } \\
\text { hyphae }\end{array}$ & \multirow{2}{*}{$\begin{array}{c}\begin{array}{c}\text { Hyphae } \\
\text { Activity }\end{array} \\
(\%)\end{array}$} & \multirow{2}{*}{$\begin{array}{c}\begin{array}{c}\text { Spore } \\
\text { number }\end{array} \\
\text { (in } \mathbf{1 0 0} \text { g soil) }\end{array}$} \\
\hline & & \multicolumn{2}{|c|}{$\left(m \operatorname{pot}^{-1}\right)$} & $(\%)$ & \multicolumn{2}{|c|}{ ( $\mathrm{m} \mathrm{g}^{-1}$ soil) } & & \\
\hline \multirow{2}{*}{$120 \mathrm{DAS}$} & $\mathrm{NO}_{3}{ }^{-}$ & $206.25(30.6)$ & $45.00(7.6)$ & $21.83(2.4)$ & $7.03(1.1)$ & $2.90(0.1)$ & $43.29(6.9)$ & $2554(264)$ \\
\hline & $\mathrm{NH}_{4}^{+}$ & $133.25(17.8)$ & $20.25(6.3)$ & $14.68(3.9)$ & $4.33(0.7)$ & $3.10(0.1)$ & $75.55(12.5)$ & 2120 (199) \\
\hline \multirow{2}{*}{$150 \mathrm{DAS}$} & $\mathrm{NO}_{3}{ }^{-}$ & $65.33(1.8)$ & $31.00(0.6)$ & $47.47(0.5)$ & $6.87(0.4)$ & $3.65(0.1)$ & $53.35(2.0)$ & 4652 (1269) \\
\hline & $\mathrm{NH}_{4}^{+}$ & $102.50(8.9)$ & $28.50(2.0)$ & $27.89(0.5)$ & $4.33(0.5)$ & $1.75(0.1)$ & $42.05(7.0)$ & $2625(412)$ \\
\hline \multirow{2}{*}{$240 \mathrm{DAS}$} & $\mathrm{NO}_{3}{ }^{-}$ & $12.27(0.7)$ & $6.72(0.1)$ & $54.99(2.0)$ & $6.03(0.4)$ & $2.60(0.2)$ & $43.68(6.0)$ & 2957 (339) \\
\hline & $\mathrm{NH}_{4}^{+}$ & $10.09(1.2)$ & $6.72(0.5)$ & $51.64(1.1)$. & $5.67(0.2)$ & $2.25(0.0)$ & $39.90(2.3)$ & $763(230)$ \\
\hline
\end{tabular}

Standard error between parentheses. 


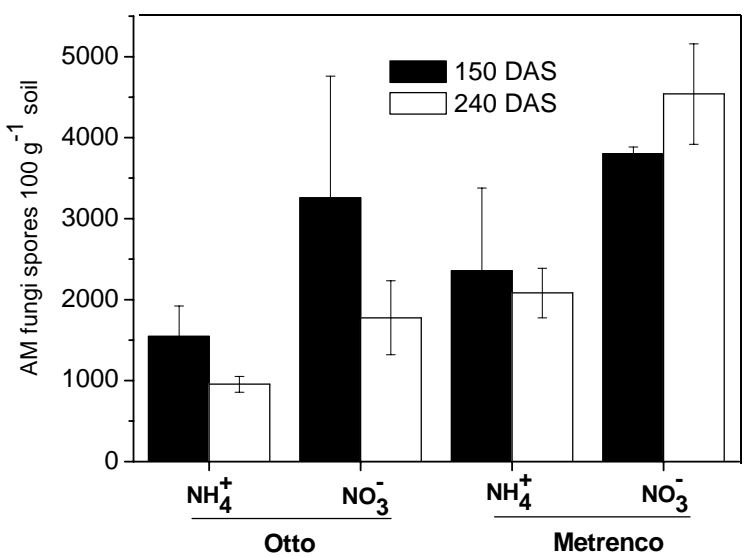

Figure 2. Persistence of indigenous AM fungi spores at 150 and 240 days after sowing (DAS) in two wheat cultivars (Otto and Metrenco) fertilized with two $\mathrm{N}$-sources $\left(\mathrm{NO}_{3}{ }^{-}\right.$and $\mathrm{NH}_{4}^{+}$). The bars represent the standard error (adapted from Cornejo et al., 2008b).

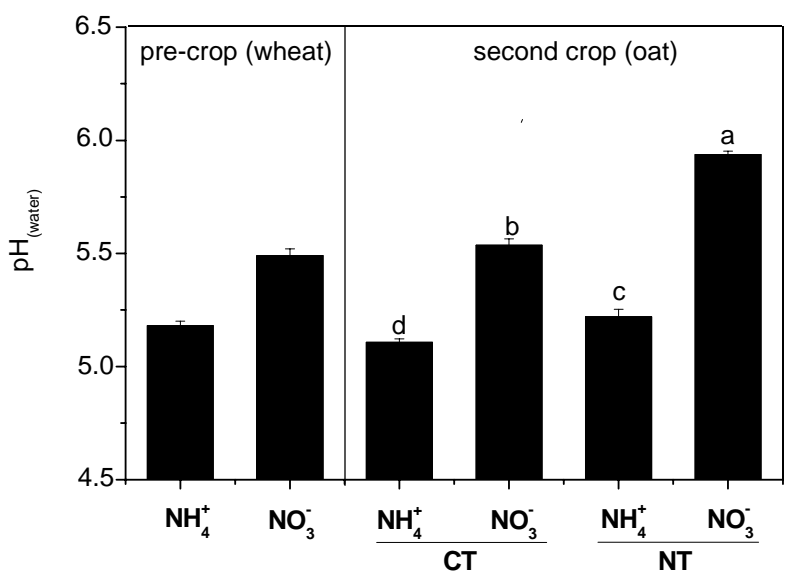

Figure 3. Soil $\mathrm{pH}$ (water) at three months post-harvest in a wheat crop (Triticum aestivum L., cv. "Otto") and at 120 days after sowing in an oat crop (Avena sativa L., cv. "Urano") in a cereal succession fertilized with two $\mathrm{N}$-sources $\left(\mathrm{NO}_{3}^{-}\right.$or $\left.\mathrm{NH}_{4}^{+}\right)$ simulating conventional tillage (CT) and no tillage (NT). The bars represent the standard error. Different letters indicate significant differences according to the orthogonal contrasts test $(\mathrm{p}<0.05)$ (adapted from Cornejo et al., 2009).

going tillage-rotation experiment made under four tillage systems: i) no-till (NT); ii) reduced tillage (RT); iii) conventional tillage with stubble mixed into the soil
(CTS); and iv) conventional tillage with stubble burnt (CTB). Soil was sampled at two dates: after wheat harvest (autumn) and six months after subsequent grassland 
Table 2. SAR $\left(\mu \mathrm{g} \mathrm{mg}^{-1}\right)$ of macroelements $(\mathrm{N}, \mathrm{P}, \mathrm{K}, \mathrm{Ca}$ and $\mathrm{Mg})$ and microelements $(\mathrm{Cu}, \mathrm{Zn}, \mathrm{Mn}$ and $\mathrm{Al})$ in mycorrhizal $(+\mathrm{M})$ and nonmycorrhizal $(-\mathrm{M})$ wheat plants as influenced by $\mathrm{N}$ source fertilizer $\left(\mathrm{NH}_{4}^{+}\right.$or $\left.\mathrm{NO}_{3}^{-}\right)$at wo crop stages $(120 \text { and } 150 \mathrm{DAS})^{*}(\mathrm{Cornejo}$ et al., 2008).

\begin{tabular}{|c|c|c|c|c|c|c|c|c|c|c|c|}
\hline \multirow{2}{*}{ Crop stage } & \multirow{2}{*}{$\mathbf{A M}$} & \multirow{2}{*}{$\mathbf{N}$ source } & \multicolumn{5}{|c|}{ Macroelements } & \multicolumn{4}{|c|}{ Microelements } \\
\hline & & & $\mathbf{N}$ & $\mathbf{P}$ & $\mathbf{K}$ & Ca & Mg & Zn & $\mathbf{C u}$ & Mn & Al \\
\hline \multirow{4}{*}{$120 \mathrm{DAS}$} & \multirow{2}{*}{$-\mathrm{M}$} & $\mathrm{NH}_{4}^{+}$ & $15.97 \mathrm{a}$ & $0.47 \mathrm{~b}$ & $9.52 \mathrm{~b}$ & $7.10 \mathrm{a}$ & $2.22 \mathrm{~b}$ & $0.026 \mathrm{~b}$ & $0.013 \mathrm{~b}$ & $0.047 \mathrm{a}$ & 0.058 \\
\hline & & $\mathrm{NO}_{3}^{-}$ & $16.23 \mathrm{a}$ & $0.33 \mathrm{c}$ & $12.63 \mathrm{a}$ & $6.40 \mathrm{a}$ & $1.82 \mathrm{~b}$ & $0.019 \mathrm{c}$ & $0.012 \mathrm{~b}$ & $0.030 \mathrm{~b}$ & 0.056 \\
\hline & \multirow{2}{*}{$+\mathrm{M}$} & $\mathrm{NH}_{4}^{+}$ & $15.97 \mathrm{a}$ & $0.58 \mathrm{a}$ & $8.90 \mathrm{~b}$ & $7.20 \mathrm{a}$ & $2.24 \mathrm{a}$ & $0.044 \mathrm{a}$ & $0.012 \mathrm{~b}$ & $0.049 \mathrm{a}$ & $0.043 \mathrm{l}$ \\
\hline & & $\mathrm{NO}_{3}^{-}$ & $18.64 \mathrm{a}$ & $0.46 \mathrm{~b}$ & $14.16 \mathrm{a}$ & $6.90 \mathrm{a}$ & $2.28 \mathrm{a}$ & $0.026 \mathrm{~b}$ & $0.017 \mathrm{a}$ & $0.028 \mathrm{~b}$ & 0.032 \\
\hline \multirow{4}{*}{150 DAS } & \multirow{2}{*}{$-\mathrm{M}$} & $\mathrm{NH}_{4}^{+}$ & $16.30 \mathrm{a}$ & $0.52 \mathrm{ab}$ & $9.83 \mathrm{~b}$ & $7.12 \mathrm{a}$ & $2.87 \mathrm{a}$ & $0.019 \mathrm{~b}$ & $0.013 \mathrm{a}$ & $0.039 \mathrm{a}$ & 0.039 \\
\hline & & $\mathrm{NO}_{3}^{-}$ & $15.73 \mathrm{a}$ & $0.47 \mathrm{~b}$ & $13.45 \mathrm{a}$ & $7.01 \mathrm{a}$ & $2.42 \mathrm{a}$ & $0.020 \mathrm{~b}$ & $0.014 \mathrm{a}$ & $0.039 \mathrm{a}$ & 0.039 \\
\hline & \multirow{2}{*}{$+\mathrm{M}$} & $\mathrm{NH}_{4}^{+}$ & $15.30 \mathrm{a}$ & $0.60 \mathrm{a}$ & $9.50 \mathrm{~b}$ & $8.13 \mathrm{a}$ & $2.78 \mathrm{a}$ & $0.026 \mathrm{a}$ & $0.013 \mathrm{a}$ & $0.029 \mathrm{~b}$ & 0.044 \\
\hline & & $\mathrm{NO}_{3}^{-}$ & $16.57 \mathrm{a}$ & $0.62 \mathrm{a}$ & $11.22 \mathrm{ab}$ & $7.38 \mathrm{a}$ & $2.64 \mathrm{a}$ & $0.026 \mathrm{a}$ & $0.011 \mathrm{a}$ & $0.022 \mathrm{c}$ & $0.025 \mathrm{~b}$ \\
\hline
\end{tabular}

$\mathrm{SAR}=$ Specific absorption rate; DAS = Days after sowing.

*For each crop stage, means followed by the same letter in a column are not significantly different using the orthogonal contrasts test $(p \leq 0.05, \mathrm{n}=16)$. 
seeding (spring). Higher $\mathrm{C}, \mathrm{N}, \mathrm{S}$, total $\mathrm{P}$, and fulvic acid-P concentrations and $\mathrm{pH}$ occurred under NT and RT than under CTS and CTB after wheat harvest (Table 3). However, results at the second sampling were not consistent (Tables 4 and 5). Arbuscular mycorrhiza spore number and active hyphal length were the highest under NT having the greatest incidence on AM root colonization and $\mathrm{P}$ concentration in pasture shoots. The concentration of glomalin, a glycoprotein produced by AM fungi (Wright and Upadhyaya, 1996; 1998), was higher under NT and RT than under CTS and CTB, but no differences were found in calculated $\mathrm{C}$-glomalin (not shown), with respect to total C (ca 5\%). It was concluded that a less disruptive effect under NT influences positively all soil characteristics and also increases $P$ acquisition by the following crop in the rotation system. These results and other related studies (Borie et al., 2000; Borie et al., 2006; Curaqueo et al., 2010) have demonstrated that reduced tillage produces beneficial effects on chemical and mycorrhizal soil characteristics which would be summarized in greater soil $\mathrm{C}$, $\mathrm{N}, \quad \mathrm{S}$ and $\mathrm{P}$ levels and AM fungal propagules left in the soil to be quickly activated for the next crop in the rotation system.

Table 3. Selected chemical properties of an Ultisol three months after wheat harvest as a function of four tillage treatments (Borie et al., 2006).

\begin{tabular}{|c|c|c|c|c|c|c|c|c|}
\hline \multirow{2}{*}{ Treatment } & $\mathbf{C}$ & $\mathbf{N}$ & $\mathbf{S}$ & \multirow{2}{*}{ pH } & Olsen-P & Total P & Fulvic-P & $\overline{\text { Humic-P }}$ \\
\hline & \multicolumn{3}{|c|}{$\left(\mathrm{g} \mathrm{kg}^{-1}\right)$} & & \multicolumn{4}{|c|}{$\left(\mathrm{mg} \mathrm{kg}^{-1}\right)$} \\
\hline NT & $67.6 \mathrm{a}$ & $5.8 \mathrm{a}$ & $1.25 \mathrm{a}$ & $5.43 \mathrm{~b}$ & $23.8 \mathrm{a}$ & $2281 \mathrm{a}$ & $387 \mathrm{a}$ & $393 \mathrm{~b}$ \\
\hline RT & $63.7 \mathrm{~b}$ & $5.6 \mathrm{~b}$ & $1.16 \mathrm{~b}$ & $5.49 \mathrm{a}$ & $19.2 \mathrm{~b}$ & $2384 \mathrm{a}$ & $417 \mathrm{a}$ & $610 \mathrm{a}$ \\
\hline CTS & $50.0 \mathrm{~d}$ & $4.4 \mathrm{c}$ & $0.9 \mathrm{c}$ & $5.26 \mathrm{~d}$ & $21.9 \mathrm{a}$ & $2063 \mathrm{~b}$ & $186 \mathrm{c}$ & $329 \mathrm{~b}$ \\
\hline СТB & $53.2 \mathrm{c}$ & $4.5 \mathrm{c}$ & $0.9 \mathrm{c}$ & $5.34 \mathrm{c}$ & $17.9 \mathrm{~b}$ & $1867 \mathrm{c}$ & $266 \mathrm{~b}$ & $413 \mathrm{~b}$ \\
\hline
\end{tabular}

NT: no-tillage; RT: reduced tillage; CTS: conventional tillage with stubble retained; CTB: conventional tillage with stubble burning. Numbers within a column, followed by the same letter are not significantly different ( $p \leq 0.05$, Duncan's Multiple Range Test).

Table 4. Selected chemical properties of an Ultisol and $\mathrm{P}$ concentration in grass shoots six months after grass sowing as a function of four tillage treatments (Borie et al., 2006).

\begin{tabular}{|c|c|c|c|c|c|c|}
\hline \multirow{2}{*}{ Treatment } & \multirow{2}{*}{$\mathbf{p H}$} & Olsen-P & Total P & Fulvic-P & Humic-P & \multirow{2}{*}{$\begin{array}{l}\text { Shoot P } \\
\left(\mathrm{mg} \mathrm{g}^{-1}\right)\end{array}$} \\
\hline & & \multicolumn{4}{|c|}{$\left(\mathrm{mg} \mathrm{kg}^{-1}\right)$} & \\
\hline NT & $5.85 \mathrm{a}$ & $36.2 \mathrm{a}$ & $2455 \mathrm{a}$ & $188 \mathrm{ab}$ & $418 \mathrm{ab}$ & $2.93 \mathrm{a}$ \\
\hline $\mathrm{RT}$ & $5.93 \mathrm{a}$ & $39.6 \mathrm{a}$ & 2379 a & $155 \mathrm{~b}$ & $524 \mathrm{a}$ & $2.75 \mathrm{~b}$ \\
\hline CTS & $5.57 \mathrm{~b}$ & $36.4 \mathrm{a}$ & $2132 \mathrm{a}$ & $217 \mathrm{a}$ & $345 \mathrm{~b}$ & $2.76 \mathrm{~b}$ \\
\hline СТB & $5.77 \mathrm{~b}$ & $37.2 \mathrm{a}$ & $2338 \mathrm{a}$ & $118 \mathrm{c}$ & $394 \mathrm{~b}$ & $2.34 \mathrm{c}$ \\
\hline
\end{tabular}

NT: no-tillage; RT: reduced tillage; CTS: conventional tillage with retained stubble CTB: conventional tillage with stubble burning. Numbers within a column, followed by the same letter are not significantly different ( $p \leq 0.05$, Duncan's Multiple Range Test). 
Table 5. Effects of four tillage treatments on mycorrhizal propagules in an Ultisol before (BS) and six months after grass sowing (AS) (Borie et al., 2006).

\begin{tabular}{|c|c|c|c|c|c|c|c|c|}
\hline \multirow[t]{3}{*}{ Treatment } & \multicolumn{2}{|c|}{$\begin{array}{c}\text { AM } \\
\text { spores }\end{array}$} & \multicolumn{2}{|c|}{$\begin{array}{c}\text { Total AM } \\
\text { hyphae }\end{array}$} & \multicolumn{2}{|c|}{$\begin{array}{c}\text { Active AM } \\
\text { hyphae }\end{array}$} & \multicolumn{2}{|c|}{ Mycorrhization } \\
\hline & \multicolumn{2}{|c|}{$\left(N^{0} 100\right.$ gds $\left.^{-1}\right)$} & \multicolumn{4}{|c|}{$\left(\mathrm{m} \mathrm{g}^{-1}\right)$} & \multicolumn{2}{|c|}{ (\%) } \\
\hline & BS & AS & BS & AS & BS & AS & BS & AS \\
\hline NT & $755 \mathrm{a}$ & $594 \mathrm{a}$ & $3.5 \mathrm{a}$ & $19.1 \mathrm{a}$ & $2.8 \mathrm{a}$ & $7.3 \mathrm{a}$ & -- & $53 \mathrm{a}$ \\
\hline RT & $731 \mathrm{a}$ & $550 \mathrm{a}$ & $3.1 \mathrm{a}$ & $10.7 \mathrm{~b}$ & $2.3 \mathrm{a}$ & $3.4 \mathrm{~b}$ & -- & $50 \mathrm{a}$ \\
\hline CTS & $452 \mathrm{~b}$ & $199 \mathrm{~b}$ & $2.5 \mathrm{a}$ & $10.5 \mathrm{~b}$ & $1.4 \mathrm{~b}$ & $3.7 \mathrm{~b}$ & -- & $36 \mathrm{~b}$ \\
\hline CTB & $372 \mathrm{c}$ & $311 \mathrm{ab}$ & $2.7 \mathrm{a}$ & $8.7 \mathrm{~b}$ & $1.3 \mathrm{~b}$ & $3.3 \mathrm{~b}$ & -- & $42 \mathrm{~b}$ \\
\hline
\end{tabular}

NT: no-tillage; RT: reduced tillage; CTS: conventional tillage with retained stubble; CTB: conventional tillage with stubble burning. Numbers within a column, followed by the same letter are not significantly different ( $p \leq 0.05$, Duncan's Multiple Range Test).

\section{Mycorrhizae and the complex acidity- Al toxicity}

Acidity is one of the most serious limitations of agricultural soils in Southern Chile. Plant growth in these acid soils especially when $\mathrm{pH}<5.5$ is generally depressed by a complex of severe conditions including excessive $\mathrm{H}^{+}$ions, $\mathrm{Al}$ and/or Mn phytoxicities together with some essential mineral nutrient deficiencies, such as $\mathrm{P}, \mathrm{Ca}, \mathrm{Mg}$ and $\mathrm{Mo}$. However, the main negative effect is assigned to $\mathrm{Al}$ which has a high phytotoxic effect on plant growth, especially at root level where water and nutrient uptake are severely reduced, mainly through the presence of $\mathrm{Al}^{3+}$, $\mathrm{Al}(\mathrm{OH})^{2+}$ and $\mathrm{Al}(\mathrm{OH})_{2}{ }^{+}$ions (all of them $\mathrm{pH}$-dependent. For overcoming $\mathrm{Al}$ toxicity, agronomists have been applying some soil management practices which decrease the levels of toxic $\mathrm{Al}$ species such as the application of organic amendments and lime, and the use of Altolerant plants alone or combined with lime. In the literature, it is widely accepted that a major plant Al-resistance mechanism involves Al-activated exudation by root apices of some organic acids (such as malic, citric or oxalic) with chelating properties, depending on the plant species studied. Hence, $\mathrm{Al}$ is rendered non toxic to the plant by an exclusion mechanism (Kochian, 1995; Pellet et al., 1995; 1998; Zheng et al., 1998; Kochian et al., 2004).

Phosphorus, $\mathrm{Ca}$ and $\mathrm{Mg}$ are elements also involved in $\mathrm{Al}$ tolerance by decreasing the activities of phytotoxic $\mathrm{Al}$ chemical species or, indirectly through an antagonistic effect on $\mathrm{Al}$ injury at physiological root level. However, the key role played in plant $\mathrm{Al}$ resistance by various rhizospheric microorganisms, especially those establishing symbiotic associations with plants, has been scarcely studied. Specifically, the role of AM fungi in such soil stress mitigation could be highly relevant.

It is well known that $\mathrm{AM}$ is a widespread terrestrial symbiosis that helps plants in nutrient acquisition (some of them antagonistic to $\mathrm{Al}$ toxicity), especially $\mathrm{P}, \mathrm{Ca}, \mathrm{Mg}, \mathrm{Cu}$ and $\mathrm{Zn}$ being the increase in $\mathrm{P}$ uptake the most important nutritional effect. On the other hand, AM fungi may be promoting $\mathrm{Al}$ resistance to 
their plant hosts as it has been recently demonstrated through an increased exudation of organic acids with chelant capacity (Klug and Cumming, 2007; 2009; Cumming and Ning, 2003). Therefore, mycorrhizal plants appear to have a higher Al tolerance than nonmycorrhizal ones, absorbing more water and nutrients. Besides, reactive $\mathrm{Al}$ activity/concentration in roots differ significantly in plants growing in symbiosis (Lux and Cumming, 2001; Klug and Cumming, 2009). The same effect has been reported by Cuenca et al., 2001) in tropical woody species Clusia multiflora, in Eucalyptus globulus by Arriagada et al., (2007) and even in an Hordeum vulgare Al-tolerant genotype (Mendoza and Borie, 1998; Borie and Rubio, 1999). In this context, Borie and
Rubio (1999) have reported the beneficial effect of the inoculation of the native ecotype of $G$. etunicatum on yield and $\mathrm{P}$, $\mathrm{Ca}$ and $\mathrm{Mg}$ acquisition by a wheat Al-tolerant genotype in comparison with an Al-sensitive one being such effect higher than lime application (Tables 6 and 7). Current research has evidenced that this beneficial effect is variable among and within AM fungal species depending on edaphic environments, suggesting the importance of fungal diversity in decreasing the adverse conditions for plant growth in acidic soils. In addition, AM FUNGI excrete significant amounts of glomalin (operationally defined as glomalin-related soil protein -GRSP-; Rillig, 2004), a glycoprotein which has structurally the potential capacity to chelate $\mathrm{Al}$ being

Table 6. Arbuscular mycorrhizal colonization (\%), spore numbers, shoot and root dry yields and root phosphatase activity (P-ase) from two barley genotypes differing in Altolerance inoculated or not with $G$. etunicatum and growing in limed and unlimed acid Andisol (Borie and Rubio, 1999).

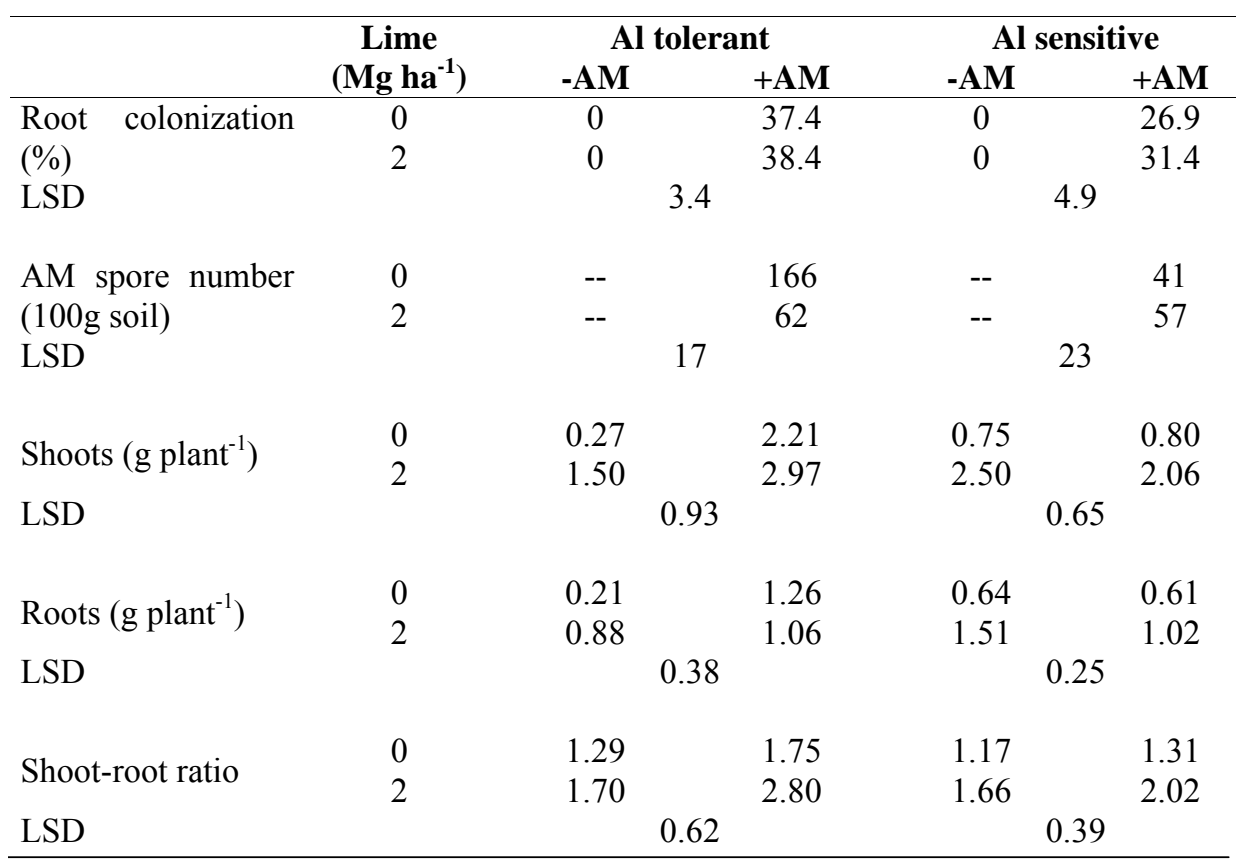


Table 7. Mycorrhizal response (MR) and lime response (LR) in terms of increase (\%) on shoot dry weight and some mineral nutrients of mycorrhizal plants over nonmycorrhizal ones and limed plants over unlimed ones of two barley genotypes differing in Al tolerance grown in an Andisol (Borie and Rubio, 1999).

\begin{tabular}{lcccc}
\hline & \multicolumn{2}{c}{ Al tolerant } & \multicolumn{2}{c}{ Al sensitive } \\
\cline { 2 - 5 } & MR (\%) & LR (\%) & MR (\%) & LR (\%) \\
\hline Shoot dry weight & 718 & 82 & 7 & 233 \\
P in shoots & 1467 & 575 & 60 & 300 \\
Ca in shoots & 1091 & 730 & 31 & 321 \\
Mg in shoots & 1312 & 500 & 81 & 438 \\
\hline \hline
\end{tabular}

an hypothetical additional mechanism that confers $\mathrm{Al}$ tolerance to plants when the symbiosis is established by efficient AM fungi.

In Chile, acid soils, mainly Andisols and Ultisols present high P-adsorption capacity and high exchangeable Al. In 2006 it was reported that about half of the 12.000 soil samples analyzed presented values higher than $12 \%$ of $\mathrm{Al}$ saturation (Bernier and Alfaro, 2006). Bearing these findings in mind, our hypothesis is that AM symbiosis confers a higher $\mathrm{Al}$ resistance to plants growing in acid volcanic soils by indirect mechanisms involving a higher nutrient acquisition, which neutralizes Al damage and/or directly by increasing root exudation of organic compounds with chelating capacity, decreasing toxic Al activity. We are now performing greenhouse and growth chamber experiments including in vivo and in vitro assays with AM native fungal ecotypes isolated from soils with a high Al saturation to demonstrate that AM symbiosis confers a higher $\mathrm{Al}$ tolerance to host plants growing in such soils.

\section{Mycorrhizae and soil aggregation}

It is important to understand the types of organic binding agents involved in soil aggregation. The nature, size, strength and aggregates configuration depend on the action of stabilizing agents which have their own hierarchal system in enmeshing particles and forming aggregates (Tisdall and Oades, 1982; Miller and Jastrow, 2000). Therefore, microbial polysaccharides stabilize macro-aggregates, whereas humic compounds stabilize microaggregates. According to Tisdall and Oades (1982), the binding agents responsible for stabilizing and arranging the aggregates are classified as temporary, transient, and persistent. Temporary agents comprise plant roots, fungal hyphae, bacterial cells, etc., being mycorrhizal hyphae one of the most important. They develop simultaneously with plant root growth building up a visible organic skeleton to enmesh the organic particles by adsorption to form young soil macroaggregates. The stabilization of these macroaggregates is carried out by the young residues entering the soil.

Persistent agents include highly decomposed organic materials such as humic compounds, polymers and polyvalent cations, but their exact chemical composition is scarcely understood. They are associated with microaggregation and long-term $\mathrm{C}$ 
sequestration. These humic compounds of high molecular weight are relatively recalcitrant forming complex structures linked to polyvalent metals (like $\mathrm{Al}$ and $\mathrm{Fe})$ or soil minerals. These types of organic compounds are very important in organic soils, such as Andisols from Southern Chile, where the bulk of organic carbon is constituted by humic substances (Aguilera et al., 2002) and where $\mathrm{Al}$ and $\mathrm{Fe}$ have high activity (Heredia et al., 2007). Persistent agents have a long effect on microaggregate dynamics but their role on the long $\mathrm{C}$ residence time in microaggregation is not understood yet (Gale et al., 2000a, 2000b). In recent years, it has been concluded that GRSP have an important role in soil aggregation (Wright and Upadhyaya, 1996; 1998; Rillig 2004; Rillig et al., 2002). However, as it has been reported by Borie et al. (2008), the relative importance of glomalin is still unclear in volcanic soils, where soil organic matter and its components involved in soil aggregation are too high.

\section{Compost addition to volcanic soils}

Soil compost application is a common soil management practice used by small farmers of Central-South Chile that produces positive effects on soil properties and also promotes presence and activity of AM fungi. Arbuscular mycorrhizal fungal presence does not only result crucial in conservation agriculture systems for its contribution to plant nutrition, but also because the establishment of the AM favors growth of the bacterial microflora adjacent to the fungus hyphae, accelerating its metabolic activity and nutrient cycle (Barea et al., 2005). On the other hand, numerous studies show that implementing conservation agriculture production systems favors root AM colonization of the grown plants and increases the number of species of this fungus type that make up their communities in the soil and inside the roots (Mäder et al., 2000; Jansa et al., 2002; Oehl et al., 2003; 2004). In addition, AM fungi can directly favor the formation of stable soil aggregates through the extension of the hyphal network that entangles small particles, and indirectly, through glomalin accumulation (Rillig, 2004; Driver et al., 2005). The recalcitrance of this glycoprotein, its hydrophobicity, and adhesiveness play important roles as cementing material of the soil particles and, at the same time, it would act as a highly stable form of organic $\mathrm{C}$ storage that could represent an important fraction of the total organic matter of the soil (Morales et al., 2005; Rillig and Mummey, 2006; Cornejo et al., 2008a).

Considering the growing interest for the use of conservation agriculture systems, such as using compost as the basis of fertilization, it becomes necessary to study the effect of its addition on the persistence and functionality of relevant microbial groups in these systems, like AM fungi, and their joint effect on the variations of physical and chemical soil characteristics. Therefore, the objective of a recent study (Valarini et al., 2009) was to analyze the effect of applying increasing doses of compost on some physical-chemical properties of an Ultisol in the Central-Southern zone of Chile, its relation to the persistence of AM fungi propagules and the functionality of the established AM symbiosis, as well as glomalin accumulation. For this reason, a cultivated soil was used with crop rotations simulating an organic agricultural system, by adding compost in greenhouse-controlled conditions, 
bean (Phaseolus vulgaris L.), and including wheat (Triticum aestivum L.), grassland (Lolium multiflorum Lam. associated with Trifolium repens L.) as the first crop of a 3-year rotation.

In general, results showed that compost application increased soil $\mathrm{pH}$, mycorrhizal roots, mycelium length, GRSP levels, and WSA (Table 8). Significant relationships were found between $\mathrm{C}$ and $\mathrm{N}$ biomass, $\mathrm{C}$ biomass and WSA, $\mathrm{C}$ biomass and GRSP, WSA and WHC, among others (Table 9). Results suggest that compost application to this type of soil is a feasible option as a fertilizer substitute, and an interesting way for avoiding soil erosion produced by small local farmers, especially those involved in organic agriculture (Valarini et al., 2009).

\section{Mycorrhizal Diversity in Chilean Forest}

In the Valdivian rainforest region of the Southern Chilean Andes three main ecosystems are found: a) the temperate evergreen primary rain forest (EF) with a diverse plant community and tree species of Nothofagus dombeyi, Laureliopsis philippiana and Podocarpus nubigena, b) the secondary deciduous forest (DF) strongly dominated by the deciduous tree species $N$. alpina, and c) grassland areas with grass species and herbs (GR). DF and GR are the successions of the clearance of the primary forest some 60 years ago. The soil in the region is an acid Andisol with high organic matter content, high exchangeable $\mathrm{Al}$ content and low levels of available $P$.

Table 8. Compost application effect on mycorrhizal spore number, root colonization percentage, fungal mycelium length, and $\mathrm{C}$ and $\mathrm{N}$ biomass at the third year of crop rotation (Valarini et al., 2009).

\begin{tabular}{|c|c|c|c|c|c|c|}
\hline Crops & $\begin{array}{l}\text { Compost } \\
\left(\mathrm{Mg} \mathrm{ha}^{-1}\right) \\
\end{array}$ & $\begin{array}{c}\text { Spores } \\
\left(\mathrm{N}^{\circ} 100 \mathrm{gss}^{-1}\right)\end{array}$ & $\begin{array}{c}\text { Myco- } \\
\text { rhization } \\
(\%)\end{array}$ & $\begin{array}{c}\text { AM } \\
\text { FUNGI } \\
\text { mycelium } \\
\left(\mathbf{m ~ g}^{-1}\right)\end{array}$ & $\begin{array}{c}\text { Biomassic } \\
\text { C } \\
\text { mg kg }^{-1} \\
\end{array}$ & $\begin{array}{c}\text { Biomassic } \\
\mathrm{N} \\
\mathrm{mg} \mathrm{kg}^{-1} \\
\end{array}$ \\
\hline \multirow{4}{*}{ Wheat } & 0 & $1366 \mathrm{aA}$ & $48.2 \mathrm{bA}$ & $1.2 \mathrm{abB}$ & $275.69 \mathrm{cB}$ & $30.20 \mathrm{bA}$ \\
\hline & 8 & $1926 \mathrm{aA}$ & $47.2 \mathrm{bA}$ & $1.4 \mathrm{aA}$ & $325.81 \mathrm{bB}$ & $37.16 \mathrm{bA}$ \\
\hline & 20 & $1310 \mathrm{aB}$ & $64.6 \mathrm{aA}$ & $1.5 \mathrm{aB}$ & $482.77 \mathrm{aB}$ & $47.94 \mathrm{aA}$ \\
\hline & 30 & $2986 \mathrm{aA}$ & $64.6 \mathrm{aA}$ & $0.6 \mathrm{bC}$ & - & - \\
\hline \multirow{4}{*}{ Bean } & 0 & $2790 \mathrm{aA}$ & $7.5 \mathrm{bB}$ & $2.1 \mathrm{aA}$ & $314.78 \mathrm{cA}$ & $34.96 \mathrm{aA}$ \\
\hline & 8 & $2390 \mathrm{aA}$ & $18.3 \mathrm{aB}$ & $1.3 \mathrm{aA}$ & $350.13 \mathrm{bB}$ & $35.68 \mathrm{aA}$ \\
\hline & 20 & $2051 \mathrm{aAB}$ & $10.8 \mathrm{abC}$ & $1.8 \mathrm{aB}$ & $499.97 \mathrm{aB}$ & $45.11 \mathrm{aA}$ \\
\hline & 30 & $2141 \mathrm{aA}$ & $37.4 \mathrm{aB}$ & $1.7 \mathrm{aB}$ & - & - \\
\hline \multirow{4}{*}{ Prairie } & 0 & $1502 \mathrm{aA}$ & $42.6 \mathrm{aA}$ & $2.2 \mathrm{bA}$ & $259.73 \mathrm{cB}$ & $33.02 \mathrm{bA}$ \\
\hline & 8 & $2031 \mathrm{aA}$ & $46.0 \mathrm{aA}$ & $2.3 \mathrm{bA}$ & $383.93 \mathrm{bA}$ & $36.92 \mathrm{bA}$ \\
\hline & 20 & $2285 \mathrm{aA}$ & $51.6 \mathrm{aB}$ & $6.3 \mathrm{aA}$ & $538.97 \mathrm{aA}$ & $51.05 \mathrm{aA}$ \\
\hline & 30 & $1956 \mathrm{aA}$ & $54.7 \mathrm{aA}$ & $2.8 \mathrm{bA}$ & - & - \\
\hline
\end{tabular}


Table 9. Main relationships between some of parameters evaluated in an experiment carried out in an Ultisol added with compost, at the third year of a crop rotation (Valarini et al., 2009).

\begin{tabular}{|c|c|c|c|c|c|c|}
\hline Parameters & $\begin{array}{c}\text { Myco- } \\
\text { rrhization }\end{array}$ & WHC $^{1}$ & $\begin{array}{c}\mathbf{D} \\
198\end{array}$ & Mycelium & $\begin{array}{c}\text { Biomassic } \\
\text { C }\end{array}$ & $\begin{array}{c}\text { Biomassic } \\
\mathrm{N}\end{array}$ \\
\hline pH & $0.30 *$ & ns & ns & $0.45 * *$ & $0.68 * *$ & $0.46 * *$ \\
\hline EE-GRSP & $0.36^{*}$ & ns & $-0.40 *$ & ns & ns & ns \\
\hline GRSP & ns & ns & ns & $0.44 * *$ & $0.35^{*}$ & $0.46 * *$ \\
\hline Aggregation & ns & $0.40^{*}$ & ns & ns & $0.57 * *$ & $0.45 * *$ \\
\hline Mycelium & ns & $\mathrm{ns}$ & ns & 1 & $0.50 * *$ & $0.47 * *$ \\
\hline Biomassic C & ns & $\mathrm{ns}$ & ns & $0.50 * *$ & 1 & $0.70 * *$ \\
\hline Biomassic N & ns & ns & ns & $0.47 * *$ & $0.70 * *$ & 1 \\
\hline
\end{tabular}

Significance conventions: ${ }^{*} p \leq 0.05 ;{ }^{*} p \leq 0.01 ; \mathrm{ns}=$ non significant $(\mathrm{n}=36)$.

${ }^{1} \mathrm{WHC}=$ water holding capacity

The objective of the studies carried out by Castillo (2005) and Castillo et al. (2005) was to investigate the diversity of mycorrhizal plants and AM fungal species in these three ecosystems. The highest diversity with 53 plant species was found in the EF with $77 \%$ of them being $\mathrm{AM}$ plants, while in GR $91 \%$ of the 20 plant species were AM plants. The DF ecosystem had only 11 plant species and the lowest proportion of AM plant species (18\%). Thirty-nine AM fungi species were found in total, of which most of them are being reported for the first time from Southern Chile. Acaulospora was the most abundant genera with 13 species, followed by Glomus with 10 species, both Scutellospora and Archaeospora with 4 species, both Pacispora and Entrophospora with 3 species, and both Paraglomus and Diversispora with one species. AM fungi species were more abundant in GR (29 spp.) than in EF (20 spp.) which is likely related to the fact that a higher proportion of AM plant species with no competition of ectomycorrhizal tree species were found in the grassland than in the EF or DF. Four AM fungi species were present in all the ecosystems, and 15 species were apparently quite specific as spores were only found in one of the ecosystems. The absolute lack of Scutellospora spp. in any of the forest ecosystems was noteworthy. It was also been stated that the diversity of AM fungi species in the ecosystems is strongly influenced by the proportion of AM plant species in each ecosystem and that it is not related to soil chemical properties (Tables 10 and 11; Castillo et al., 2005). The same author has also reported the diversity of AM fungi populations in an Ultisol subjected to notillage and conventional tillage and crop rotation founding a higher spore number and diversity than those observed in forest soils (Castillo, 2005; Castillo et al., 2006). 
Table 10. Number of spores of arbuscular mycorrhizal fungi in the Chilean temperate rainforest region (Castillo et al., 2005).

\begin{tabular}{cc}
\hline Ecosystems $^{\mathbf{1}}$ & $\begin{array}{c}\text { Spore number } \\
\text { per } \mathbf{1 0 0} \text { g of soil }^{2}\end{array}$ \\
\hline EF & $3164 \mathrm{a}$ \\
DF & $456 \mathrm{c}$ \\
GR & $1001 \mathrm{~b}$ \\
\hline
\end{tabular}

${ }^{1} \mathrm{EF}$ : evergreen forest ecosystem; DF: deciduous forest ecosystem; GR: grassland ecosystem. ${ }^{2}$ Average for five replicates. Treatment means followed by the same letter are not significantly different $(p \leq 0.05)$.
From these studies we can conclude that the only way to maintain high plant species diversity with its associated AM plant community is by preserving this native rainforest ecosystem. Grasslands with a broad plant species community appear to be a good alternative for the native evergreen rainforests in conserving a high AM fungi biodiversity, but it is clear that this behavior is occurring at expense of the forest vegetation diversity. The deciduous secondary forest with an almost mono-specific $N$. alpina cover appears to be economically attractive at first view, but finally resulting in an ecological degraded ecosystem with low biodiversity including low diversity of AM fungi species.

Table 11. Absolute and relative numbers of arbuscular mycorrhizal fungal species in different genera in the Chilean temperate rainforest region (Castillo et al., 2005).

\begin{tabular}{|c|c|c|c|c|c|c|c|c|}
\hline \multirow[t]{2}{*}{ AM Fungi genus } & \multicolumn{2}{|c|}{ EF* } & \multicolumn{2}{|c|}{ DF } & \multicolumn{2}{|c|}{ GR } & \multicolumn{2}{|c|}{$\begin{array}{c}\text { Total number } \\
\text { species }\end{array}$} \\
\hline & Abs. ${ }^{a}$ & Rel. $^{b}$ & Abs. & Rel. & Abs. & Rel. & Abs. & Rel. \\
\hline Acaulospora spp. & 7 & 35 & 4 & 29 & 12 & 42 & 13 & 33 \\
\hline Archaeospora spp. & 2 & 10 & 2 & 14 & 3 & 10 & 4 & 10 \\
\hline Diversispora spp. & 1 & 5 & 0 & 0 & 1 & 3.25 & 1 & 2.5 \\
\hline Entrophospora spp. & 2 & 10 & 2 & 14 & 1 & 3.25 & 3 & 8 \\
\hline Glomus spp. & 6 & 30 & 5 & 36 & 6 & 21 & 10 & 26 \\
\hline Pacispora spp. & 2 & 10 & 1 & 7 & 1 & 3.25 & 3 & 8 \\
\hline Paraglomus spp. & 0 & 0 & 0 & 0 & 1 & 3.25 & 1 & 2.5 \\
\hline Scutellospora spp. & 0 & 0 & 0 & 0 & 4 & 14 & 4 & 10 \\
\hline Total number species & 20 & 100 & 14 & 100 & 29 & 100 & 39 & 100 \\
\hline
\end{tabular}

*EF: evergreen forest ecosystem; DF: deciduous forest ecosystem; GR: grassland ecosystem.

${ }^{\mathrm{a}}$ Abs.: Absolute; ${ }^{\mathrm{b}}$ Rel.: Relative. 
Hence, if the aim is to optimize the utilization and economies of primary and secondary forests in Southern Chile while maintaining a high biodiversity of plants and beneficial microorganisms in soil, we can make the following suggestions, in terms of forest management practices:

- No question that native rainforest areas should be conserved because it seems, as shown by the successional deciduous forest and the grassland in Valdivian temperate rainforest areas, that there is no way back to high plant species diversity. However, it is likely that a selective and careful extraction of some precious wood will not unbalance this system so that its utilization is possible.

- Deciduous forests could be utilized more intensively extracting more timber and thinning the crowns more than it is currently done. This is proposed with the expectation that grasses, herbs, shrubs and native evergreen forest species invade the secondary forest to establish diverse vegetation again. This is the way to recover higher micro-organism diversity, too.

- Grassland areas should be maintained by cattle grazing as this will likely inhibit the establishment of a mono-specific deciduous secondary forest with $N$. alpina. These grasslands in Southern Chile should not be converted into monospecific pine or eucalyptus plantations, as it is currently performed in large areas of Central Chile. Both mono-specific secondary forest and mono-specific forest plantations will result in ecosystems with extremely poor bio-diversity. If grasslands are to be re-forested, appropriate native tree species should be used of which a minimum of $50 \%$ should be AM to maintain a bio-diversity of EM and AM vegetation similar to the current evergreen rainforest of the region (Castillo, 2005).
There is increasing evidence suggesting that accretion of microbial turnover products is an important agent of control for isotopic $\mathrm{C}$ and $\mathrm{N}$ enrichment of soil organic matter. Ectomycorrhizal and saprophytic fungal products have been considered to be an important driver for such enrichment, but AM fungi contribution is scarcely studied. The aim of a study carried out in the same forest ecosystems as above (Etcheverría, 2009) was to compare $\delta^{13} \mathrm{C}$ and $\delta^{15} \mathrm{~N}$ patterns of GRSP, litter and bulk soil profiles in four of such N-limited forests of Southern Chile. As GRSP is a glycoprotein derived from AM fungi contributes slightly to $\mathrm{C}$ and $\mathrm{N}$ leaching (Rillig et al., 2006), it results in a recalcitrant SOM fraction strongly stabilized to the soil matrix) Hence, $\delta^{13} \mathrm{C}$ and $\delta^{15} \mathrm{~N}$ enriched turnover compounds derived from AM fungi biomass appear to account for a large percentage of the total $\mathrm{C}$ and $\mathrm{N}$ contained in SOM. From these studies, it was concluded that AM fungi are involved in the accumulation over time of such compounds under the form of recalcitrant SOM in deeper soil layers according to soil depth (Table 12; Etcheverría et al., 2009).

In the study of forest ecosystems carried out by Etcheverría (2009), she also determined $\mathrm{C}, \mathrm{N}, \mathrm{Fe}$ and $\mathrm{Al}$ contents in GRSP. Carbon and N levels were about the same reported by earlier studies (Nichols and Wright, 2005; Wright and Upadhyaya, 1996; 1998; Rillig, 2004) ranging from 29.4 to $33.2 \%$ and 2.5 to $3.1 \%$ for $\mathrm{C}$ and $\mathrm{N}$, respectively with an average of 31.4 and $2.8 \%$.It has been suggested that $\mathrm{Fe}$ gives GRSP a higher recalcitrance facing microbial attack. In these ecosystems, Al contents were higher than $\mathrm{Fe}$ ones (average $4.7 \%$ for $\mathrm{Fe}$ compared with $5.2 \%$ for $\mathrm{Al}$, respectively) being the first report connecting Glomalin 
Table 12. Total $\mathrm{C}(\mathrm{TC})$ and nitrogen $(\mathrm{TN})$ content and \% contribution to total soil $\mathrm{C}$ and $\mathrm{N}$ content of glomalin-related soil protein (GRSP) in the four south-Chilean forests stands (Etcheverría et al., 2009)

\begin{tabular}{lccccc}
\hline \multirow{2}{*}{ Forest stand } & Depth (cm) & \multicolumn{2}{c}{$\begin{array}{c}\text { GRSP content } \\
\left(\mathbf{m g ~ g}^{-1} \text { soil) }\right.\end{array}$} & \multicolumn{2}{c}{ \% of total soil (\%) } \\
\cline { 3 - 6 } & & TC & TN & TC & TN \\
\hline \multirow{2}{*}{ UEF* $^{*}$} & $0-20$ & $12.7(0.4)$ & $1.29(0.17)$ & $8.6(1.2)$ & $11.5(3.6)$ \\
& $20-40$ & $7.6(1.0)$ & $0.80(0.12)$ & $7.9(1.3)$ & $9.8(2.4)$ \\
MEF & $0-20$ & $18.0(1.2)$ & $1.79(0.14)$ & $9.0(2.2)$ & $12.8(2.7)$ \\
& $20-40$ & $9.1(1.0)$ & $0.78(0.14)$ & $8.3(1.6)$ & $10.2(2.9)$ \\
UDF & $0-20$ & $28.1(7.2)$ & $2.16(0.31)$ & $15.4(8.3)$ & $18.5(4.7)$ \\
& $20-40$ & $15.4(4.9)$ & $1.22(0.27)$ & $11.5(4.4)$ & $15.2(5.8)$ \\
\multirow{2}{*}{ MDF } & $0-20$ & $15.3(2.1)$ & $1.45(0.23)$ & $8.3(1.6)$ & $13.1(4.4)$ \\
& $20-40$ & $9.9(0.3)$ & $0.99(0.09)$ & $8.3(1.7)$ & $14.0(2.7)$ \\
\hline
\end{tabular}

*Abbreviations: UEF = undisturbed evergreen forest, MEF $=$ managed evergreen forest, UDF = undisturbed deciduous forest, $\mathrm{MDF}=$ managed deciduous forest. Standard deviations between parentheses.

stability with $\mathrm{Al}$ in agro or forest ecosystems. Such higher Al concentration in GRSP could be suggesting a new role played by AM fungi in giving a higher $\mathrm{Al}$ tolerance to mycorrhizal host plants growing in habitats with phytotoxic Al.

\section{FINAL CONSIDERATIONS CONCLUSIONS}

The particular properties of volcanic soils from Southern Chile determine that the native AM fungi populations play a key role in the sustainability and productivity of plant ecosystems established there. As aforementioned, this role is not only preponderant in agricultural ecosystems, but also in natural and even forest ecosystems, where the presence of these type of fungi is often lower, or their contribution is less significant compared with other mycorrhiza types (mainly ectomycorrhizae and ericoid mycorrhizae). In this regard, the several studies carried out in our research group highlight a series of aspects that should be considered to a better management of the soil resource in order to maximize the benefits of the AM symbiosis under conditions commonly limiting for the plant establishment and growth. Additionally, on the evidence of global climate change, which is worldwide recognized to be the product of an increase in the emission of greenhouse gases (mainly C compounds), it is interesting to highlight not only the high capacity of volcanic soils to store large amounts of organic $\mathrm{C}$, but also the high $\mathrm{C}$ proportion that is stored by mycorrhizal 
way, which reinforces the idea of choosing the best management options to promote the presence of larger and more functional native AM fungal populations. However, the current changes in agricultural and forestry production systems in Southern Chile, and the reorientation of them towards more intensive systems require the development of biotechnological tools, among which the selection of efficient native AM fungal ecotypes and their incorporation into biofertilizers emerges as a need. Indeed, this need will guide and concentrate the future scientific and technological research in arbuscular mycorrhizae in Chile to be accomplished by our group.

\section{REFERENCES}

Aguilera, M., Mora, M.L., Borie, G., Peirano, P., Zunino, H. 2002. Balance and distribution of sulphur in volcanic ash-derived soils in Chile. Soil Biol. Biochem. 34:1355-1361.

Alvear, M., López, R., Rosas, A., Espinoza, N. 2006. Efecto de la aplicación de herbicidas en condiciones de campo sobre algunas actividades biológicas. R.C. Suelo Nutr. Veg. 6(1): 64-76.

Alvear, M., Urra, C., Huaiquilao, R., Astorga, M., Reyes, F. 2007. Actividades biológicas y estabilidad de agregados en un suelo del bosque templado chileno bajo dos etapas sucesionales y cambios estacionales. R.C. Suelo Nutr. Veg. 7(3): $38-50$.

Arriagada, C.A., Herrera, M.A., Borie, F., Ocampo, J.A. 2007. Contribution of arbuscular mycorrhizal and saprobe fungi to the aluminum resistance of Eucalyptus globulus. Water Air Soil Poll. 182(1-4): 383-394.

Azcón, R., Gómez, M., Tobar, R. 1992. Effects of nitrogen-source on growth, nutrition, photosynthetic rate and nitrogen-metabolism of mycorrhizal and phosphorus-fertilized plants of Lactuca-sativa L. New Phytol. 121(2): 227-234.

Bago, B., Vierheiling, H., Piche, Y., AzcónAguilar, C. 1996. Nitrate depletion and $\mathrm{pH}$ changes induced by the extraradical mycelium of the arbuscular mycorrhizal fungus Glomus intraradices grown in monoxenic culture. New Phytol.133(2): 273-280.

Bago, B., Azcón-Aguilar, C. 1997. Changes in the rhizospheric $\mathrm{pH}$ induced by arbuscular mycorrhiza formation in onion (Allium cepa $\mathrm{L}$ ). Z. Pflanz. Bodenk. 160(3): 333-339.

Bago, B., Pfeffer, P., Shachar-Hill, Y. 2001. Could the urea cycle be translocating nitrogen in the arbuscular mycorrhizal symbiosis? New Phytol. 149: 4-8.

Barea, J.M., Pozo, M.J., Azcón, R., AzcónAguilar, C. 2005. Microbial co-operation in the rhizosphere. J. Exp. Bot. 56:1761-1778

Bernier, R., Alfaro, M. 2006. Acidez de los suelos y efecto del encalado. Bol. INIA 151: 746.

Besoain, M.E. 1985. Génesis y transformación de los minerales de arcilla en suelos derivados de cenizas volcánicas del centro-sur de Chile. In: Tosso, J. (Ed.). Suelos Volcánicos de Chile. Instituto de Investigaciones Agropecuarias. Centro de Investigación La Platina. Santiago, Chile. p. 275-284.

Borie, F., Fuentealba, F. 1982. Bioquímica de suelos derivados de cenizas volcánicas. II. Actividad ureásica. Agric. Téc. (Chile) 42: 135141.

Borie, F., Rubio, R., Schalchli, C. 1998. Micorrizas arbusculares y actividad fosfatásica de diez cultivares de trigo. Agric. Téc. (Chile) 58: 47-55.

Borie, F., Rubio, R. 1999. Effects of arbuscular mycorrhizae and liming on growth and mineral acquisition of aluminium-tolerant and aluminium-sensitive barley cultivars. J. Plant Nutr. 22: 121-137.

Borie, F., Rubio, R., Morales, A., Castillo, C. 2000. Relación entre densidad de hifas de hongos micorrizógenos arbusculares y producción de glomalina con las características físicas $\mathrm{y}$ químicas de suelos bajo cero labranza. Rev. Chil. Hist. Nat. 73: 749-756.

Borie, F., Redel, Y., Rubio, R., Rouanet, J.L., Barea, J.M. 2002. Interactions between crop residues applications and mycorrhizal developments and some soil-root interface properties and mineral acquisition by plants in an acidic soil. Biol. Fertil. Soils 36(2): 151-160. 
Borie, F., Rubio, R., Rouanet, J. L., Morales, A., Borie, G., Rojas, C. 2006. Effects of tillage systems on soil characteristics, glomalin and mycorrhizal propagules in a Chilean Ultisol. Soil Till. Res. 88(1-2): 253-261.

Borie, F., Rubio, R., Morales, A. 2008. Arbuscular mycorrhizal fungi and soil aggregation. J. Soil Sci. Plant Nutr. 8: 9-18.

Castillo, C. 2005. Biodiversidad y efectividad de hongos micorrízicos arbusculares en ecosistemas agro-forestales del Centro-Sur de Chile. PhD Thesis in Sciences of Natural Resources, Universidad de La Frontera (Chile), 124 p.

Castillo, C., Borie, F., Godoy, R., Rubio, R., Sieverding, E. 2005. Diversity of mycorrhizal plant species and arbuscular mycorrhizal fungi in evergreen forest, deciduous forest and grassland ecosystems of Southern Chile. J. Appl. Bot. Food Qual. 80:40-47.

Castillo, C., Rubio, R., Rouanet, J.L, Borie, F. 2006. Early effects of tillage and crop rotation on arbuscular mycorrhizal fungal propagules in an Ultisol. Biol. Fert. Soils 43: 83-92.

Clark, R.B., Zeto, S.K. 2000. Mineral acquisition by arbuscular mycorrhizal plants. J. Plant Nutr. 23(7): 867-902.

Clark, R.B., Zobel, R.W., Zeto, S.K. 1999. Arbuscular mycorrhizal fungal isolate effectiveness on growth and root colonization of Punicum virgatum in acid soil. Soil Biol Biochem. 31: 1757-1763.

Cornejo, P., Borie, F., Rubio, F., Azcón, R. 2007. Influence of nitrogen source on the viability, functionality and persistence of Glomus etunicatum fungal propagules in an Andisol. Appl. Soil Ecol. 35(2): 423-431.

Cornejo, P., Meier, S., Borie, G., Rillig, M., Borie, F. 2008a. Glomalin-related soil protein in a Mediterranean ecosystem affected by a copper smelter and its contribution to $\mathrm{Cu}$ and $\mathrm{Zn}$ sequestration. Sci. Total Environ. 406:154-160.

Cornejo, P., Rubio, R., Castillo, C., Azcón, R. Borie, F. 2008b. Mycorrhizal effectiveness on wheat nutrient acquisition in an acidic soil from Southern Chile as affected by nitrogen sources. J. Plant Nutr. 31(9): 1555-1569.

Cornejo, P., Rubio, R., Borie, F. 2008c. Effect of nitrogen source on some rhizospheric properties and persistence of mycorrhizal fungal propagules in an andisol. Chilean J. Agric. Res. 68(2): 119-127.
Cornejo, P., Rubio, R., Borie, F. 2009. Mycorrhizal propagule persistence in a succession of cereals in a disturbed and undisturbed andisol fertilized with two nitrogen sources. Chilean J. Agric. Res. 69(3): 426-434.

Cuenca, G., Azcón, R. 1994. Effects of ammonium and nitrate on the growth of VAmycorrhizal Erythrina poeppigiana O.I, cook seedlings. Biol. Fert. Soils 18: 249-254.

Cuenca, G., De Andrade, Z., Meneses, E. 2001. The presence of aluminum in arbuscular mycorrhizas of Clusia multiflora exposed to increased acidity. Plant Soil 231(2): 233-241.

Cumming, J.R., Ning, J. 2003. Arbuscular mycorrhizal fungi enhance aluminum resistance of broomsedge (Andropogon virginicus L.). J. Exp. Bot. 54: 1447-1459.

Curaqueo, G., Acevedo, E., Cornejo, P., Seguel, A., Rubio, R., Borie, F. 2010. Tillage effect on soil organic matter, mycorrhizal hyphae and aggregates in a mediterranean agroecosystem. R. C. Suelo Nutr. Veg. 10(1): 1221.

Driver, J.D., Holben, W.E., Rillig, M.C. 2005. Characterization of glomalin as a hyphal wall component of arbuscular mycorrhizal fungi. Soil Biol. Biochem. 37:101-106.

Etcheverría, P. 2009. Glomalina en bosques templados y en una plantación de Pseudotsuga menziesii en la Cordillera de Los Andes, CentroSur de Chile. PhD Thesis in Sciences of Natural Resources, Universidad de La Frontera (Chile), $134 \mathrm{p}$

Etcheverría, P., Huygens, D., Godoy, R., Borie, F., Boeckx, P. 2009. Arbuscular mycorrhizal fungi contribute to ${ }^{13} \mathrm{C}$ and ${ }^{15} \mathrm{~N}$ enrichment of soil organic matter in forest soils. Soil Biol. Biochem. 41: 858-861.

Gale, W.J., Cambardella, C.A., Bailey, T.B. 2000a. Surface residue- and root-derived carbon in stable and unstable aggregates. Soil Sci. Soc. Am. J. 64(1): 196-201.

Gale, W.J., Cambardella, C.A., Bailey, T.B. 2000b. Root-derived carbon and the formation and stabilization of aggregates. Soil Sci. Soc. Am. J. 64(1): 201-207.

Gerendás, J., Zhu, Z., Bendixen, R., Rateliffe, R.G., Sattelmacher, B. 1997. Physiological and biochemical processes related to ammonium toxicity in higher plants. Z. Pflanz. Bodenk. 160: 239-251. 
Hawkins, H.J., George, E. 2001. Reduced N15-nitrogen transport through arbuscular mycorrhizal hyphae to Triticum aestivum L. supplied with ammonium vs. nitrate nutrition. Ann. Bot-London 87(3): 303-311.

Hawkins, H.J., Johansen, A., George, E. 2000. Uptake and transport of organic and inorganic nitrogen by arbuscular mycorrhizal fungi. Plant Soil 226(2): 275-285.

Heredia, W., Peirano, P., Borie, G., Zunino, H., Aguilera, M. 2007. Organic carbon balance in Chilean volcanic soils after human intrusion and under different management practices. Acta Agr. Scand. B-S P 57(4): 329-334.

Jansa, J., Mozafar, A., Anken, T., Ruh, R., Sanders, I.R., Frossard, E. 2002. Diversity and structure of AM FUNGI communities as affected by tillage in a temperate soil. Mycorrhiza 12:225234.

Jeffries, P., Barea, J.M. 2001. Arbuscular Mycorrhiza: a key component of sustainable plant-soil ecosystems. In: B. HOCK. The Mycota vol. IX Fungal Associations. Ed. SpringerVerlag, Berlin, Heildelberg, pp. 95-113.

Johansen, A. 1999. Depletion of soil mineral N by roots of Cucumis sativus L-colonized or not by arbuscular mycorrhizal fungi. Plant Soil 209(1): 119-127.

Kabir, Z. 2005. Tillage or no-tillage: Impact on mycorrhizae. Can. J. Plant Sci. 85(1): 23-29.

Kochian, L.V. 1995. Cellular mechanisms of aluminum toxicity and resistance in plants. Annu. Rev. Plant Physiol. Plant Mol. Biol. 46: 237-260.

Kochian, L.V., Hoekenga, O.A., Piñeros, M.A 2004. How do crop plants tolerate acid soils? Mechanisms of aluminum tolerance and phosphorous efficiency. Annu. Rev. Plant Biol. 55: 459-493.

Klugh, K., Cumming, J. 2007. Variations in organic acid exudation and aluminum resistance among arbuscular mycorrhizal species colonizing Liriodendron tulipifera. Tree Physiol. 27: 11031112.

Klug, K., Cumming, J. 2009. Organic acid exudation by mycorrhizal Andropogon virginicus L. (broomsedge) roots in response to aluminum. Soil Biol. Biochem. 41: 367-373.

López-Pedrosa, A., Gonzalez-Guerrero, M., Valderas, A., Azcón-Aguilar, C., Ferrol, N. 2006. GintAMT1 encodes a functional high- affinity ammonium transporter that is expressed in the extraradical mycelium of Glomus intraradices. Fungal Genet. Biol. 43(2): 102110.

Lux, H.B., Cumming, J.R. 2001. Mycorrhizae confer aluminum tolerance to tulip-poplar seedlings. Can J. For. Res. 31: 694-702.

Mäder, P., Edenhofer,S., Boller, T., Wiemken, A., Niggli, U. 2000. Arbuscular mycorrhizae in a long-term field trial comparing low-input (organic biological) and high-input (conventional) farming systems in a crop rotation. Biol. Fert. Soils 31:150-156.

Martens, D. 2001. Nitrogen cycling under different soil management systems. Adv. Agron. 70:143-189.

Mendoza, J., Borie, F. 1998. Effect of Glomus etunicatum inoculation on aluminum, phosphorus, calcium, and magnesium uptake of two barley genotypes with different aluminum tolerance. Commun. Soil Sci. Plant Anal. 29(56): 681-695.

Miller, R.M., Jastrow, J.D. 2000. Mycorrhizal fungi influence soil structure. In: Arbuscular Mycorrhizas: physiology and function, Y. Kapulnik and D. Douds, eds. Kluwer Academic Publishers, Dordrecht, p 4-18.

Morales, A., Castillo, C.G., Rubio, R., Godoy, R., Rouanet, J.L., Borie, F. 2005. Niveles de glomalina en suelos de dos ecosistemas del Sur de Chile. Rev. Cienc. Suelo Nutr. Veg. 5(1):3745.

Nakamura, T., Adu-GyAM fungií, J.J., Yamamoto, A., Ishikawa, S., Nakano, H., Ito, O. 2002. Varietal differences in root growth as related to nitrogen uptake by sorghum plants in low-nitrogen environment. Plant Soil 245(1): 1724.

Nichols, K., Wright, S. 2005. Comparison of glomalin and humic acid in eight native US soils. Soil Sci. 170: 985-997.

Oehl, F., Sieverding, E., Ineichen, K., Mäder, P., Boller, T., Wiemken, A. 2003. Impact of land use intensity on the species diversity of arbuscular mycorrhizal fungi in agroecosystems of Central Europe. Appl. Environ. Microbiol. 69:2816-2824.

Oehl, F., Sieverding, E., Mader, P., Dubois, D., Ineichen, K., Boller, T., Wiemken, A. 2004. 
Impact of long-term conventional and organic farming on the diversity of arbuscular mycorrhizal fungi. Oecologia 138:574-583.

Pellet, D.M., Grunes, D.L., Kochian, L.V. 1995. Organic acid exudation as an aluminumtolerance in maize (Zea mays L.). Planta 196: 788-795.

Pellet, D.M., Papernik, L.A., Kochian. L.V. 1996. Multiple aluminum-resistance mechanisms in wheat. Roles of root apical phosphate and malate exudation. Plant Physiol. 112:591-597.

Peirano, P., Aguilera, S.M., Borie, G., Caiozzi, M. 1992. Actividad biológica en suelos volcánicos y su relación con la dinámica de la materia orgánica. Agric. Téc. 52: 367-371.

Redel, Y., Rubio, R., Rouanet, J.L., Borie, F. 2007. Phosphorus bioavailability affected by tillage and crop rotation on a Chilean volcanic derived Ultisol. Geoderma 139(3-4): 388-396.

Rillig, M.C. 2004. Arbuscular mycorrhizae, glomalin, and soil aggregation. Can J. Soil Sci. 84:355- 363

Rillig, M.C., Wright, S.F., Eviner,V. 2002. The role of arbuscular mycorrhizal fungi and glomalin in soil aggregation: comparing effects of five plant species. Plant Soil 238:325-333.

Rillig, M.C., Mummey, D.L. 2006 Mycorrhizas and soil structure. New Phytol. 171:41-53.

Rillig, M.C., Hoye, A.T., Carran, A. 2006. Minimal direct contribution of abuscular mycorrhizal fungi to DOC leaching in grassland through losses of glomalin-related soil protein. Soil Biol. Biochem. 38: 2967-2970.

Rubio, R., Borie, F., Schalchli, C., Castillo, C., \& Azcón, R. 2003. Occurrence and effect of arbuscular mycorrhizal propagules in wheat as affected by source and amount of phosphorus fertilizer and fungal inoculation. Appl. Soil Ecol. 23: $245-255$.

Siqueira, J.O., Moreira, F.M.S. 1997 Microbia populations and activities in highly-weathered acidic soils: highlights of the brazilian research In: Moniz AC, Furlani AMC, Schaffert RE, Fageria NK, Rosolem CA, Cantarella H (eds) Plant-soil interactions at low $\mathrm{pH}$ : sustainable agriculture and forestry production. Brazilian Soil Science Society, Campinas/Viçosa, Brazil, pp 139-156.
Stange, B., Beratto, E., Montenegro, A., Peyrelongue, A., Borie, F. 1995. Effect of nitrogen source on barley growing in a high aluminium content soil. Agric. Téc. (Chile) 55:118-126.

Tisdall, J.M., Oades, J.M. 1982. Organic matter and water-stable aggregates in soils. J. Soil Sci. 33:141-163.

Valarini, P.J., Curaqueo, G., Seguel, A., Manzano, K., Rubio, R., Cornejo, P., Borie, F. 2009. Effect of compost application on some properties of a volcanic soil from Central South Chile. Chilean J. Agric. Res. 69: 416-425.

Wright, S.F., Upadhyaya, A. 1996. Extraction of an abundant and unusual protein from soil and comparison with hyphal protein of arbuscular mycorrhizal fungi. Plant Soil 198:97-107.

Wright, S.F., Upadhyaya, A. 1998. A survey of soils for aggregate stability and glomalin, a glycoprotein produced by hyphae of arbuscular mycorrhizal fungi. Plant Soil 198: 97-107.

Zheng, S.J., Ma, J.F., Matsumoto, H. 1998. High Aluminum resistance in buckwheat. Alinduced specific secretion of oxalic acid from root tips. Plant Physiol. 117: 745-751.

Zunino, H., Borie, F., Aguilera, M., Martin, J.P., Haider, K. 1982a. Decomposition of ${ }^{14} \mathrm{C}$ labeled glucose, plant and microbial products and phenols in volcanic ash-derived soils of Chile. Soil Biol. Biochem. 14: 37-43.

Zunino, H., Peirano, P., Caiozzi, M., Martin, J.P. 1982b. Decomposition of 14C-labeled lignins, model humic acid polymers, and fungal melanins in allophanic soils. Soil Biol. Biochem. 14: $289-293$

Zunino, H., Aguilera, M., Peirano, P., Caiozzi, M., Rex, A. 1982c. Bioquímica de suelos derivados de cenizas volcánicas. III. Síntesis microbiana de polímeros húmicos y su capacidad de adsorción de Zn (II) y Mg (II). Agric. Téc. 42: 287-292. 